\title{
Effects of Extracts from Two Combretaceae Anogeissus leiocarpus (DC) Guill. and Perr. and Terminalia macroptera Guill. and Perr. on the Pseudomonas aeruginosa PAO1 Pathogenicity in Nicotiana tabacum L.
}

\begin{abstract}
Safiétou Ouédraogo ${ }^{{ }^{*}}$, Razacswendé Fanta Ouédraogo ${ }^{2}$, Vincent Ouedraogo ${ }^{1}$, Pierre Alexandre Eric Djifaby Sombié ${ }^{3}$, Moussa Compaoré ${ }^{1,4}$ and Martin Kiendrebeogo $0^{1,4}$

${ }^{1}$ Laboratory of Applied Biochemistry and Chemistry (LABIOCA), UFR-SVT, University Joseph KIZERBO, 03 BP 7021 Ouagadougou 03, Burkina Faso.

${ }^{2}$ Biosciences Laboratory, UFR-SVT, University Joseph KI ZERBO, 03 BP 7021, Ouagadougou 03, Burkina Faso. ${ }^{3}$ Plant Production Department, Institute of the Environment and Agricultural Research (INEAR)/ National Center for Scientific and Technological Research (NCSTR), Burkina Faso. ${ }^{4}$ Platform of Cell and Tissue Culture (PCCT) UFR-SVT, University Joseph KI ZERBO, 09 BP 1001, Ouagadougou 09, Burkina Faso.
\end{abstract}

Authors' contributions

This work was carried out in collaboration among all authors. Author SO wrote the protocol, performed the statistical analysis. Authors SO and RFO wrote the first draft of the manuscript. Authors RFO, VO, PAEDS and MC managed the analyses of the study. Author MK designed the study and managed the literature searches. All authors read and approved the final manuscript.

Article Information

DOI: $10.9734 / A R R B / 2020 / v 35 i 1030294$ Editor(s):

(1) Dr. Bechan Sharma, University of Allahabad, India. Reviewers: (1) Abdelhalim Abdullahi Hamza Ahmed, National Centre for Research, Sudan. (2) Maysaa Ali Abdul Khaleq, Al-Rasheed University College, Iraq. Complete Peer review History: http://www.sdiarticle4.com/review-history/61801

Original Research Article

Received 02 August 2020 Accepted 09 October 2020 Published 29 October 2020 


\section{ABSTRACT}

Aims: This study aimed to assess the ability of methanolic bark extracts from medicinal plants, Anogeissus leiocarpus and Terminalia macroptera for reducing Pseudomonas aeruginosa PAO1 bacteria pathogenicity in Nicotiana tabacum.

Study Design: A complete randomized block design was used with 3 replications including 3 infiltrations modes: PAO1 only, PAO1+ A. leiocarpus extract, PAO1+ T. macroptera extract; the control plants didn't received infiltration.

Place and Duration of Study: The study was conducted at the Laboratory of Biochemistry and Chemistry Applied and Plant Ecophysiology Laboratory, University Joseph KI-ZERBO between November 2018 and May 2019.

Methodology: Six weeks old tobacco plants previously cultured in vitro were infected via infiltration of bacterial inoculum with or not plant extract into Arabidopsis leaves. Ten days after the infection, phenotypic and biochemical leaves parameters were evaluated. The ImageJ software was used to measure discolored and necrotic surfaces. Chlorophyll a and b, proteins, total polyphenols and total flavonoids foliar contents were determined by spectrophotometry.

Results: The extracts of plants used reduced significantly the severity of chlorosis and necrosis. They also allowed to increase the chlorophyll a but lowered the total flavonoids contents. $T$. macroptera extract showed an important reduction potential of necrotic area and total flavonoid content, and led to a decrease of total polyphenol content. A. leiocarpus extract application improved the protein content.

This antibacterial activity seems attributable to the content in secondary metabolites including polyphenols acting alone or in synergy with those synthesized by tobacco. In addition, it appears that i) total polyphenols content make $T$. macroptera the most effective extract plant on foliar necrosis and that ii) perhaps other(s) class(es) of extract polyphenol, different of flavonoids, is (are) involved in the protective action on leaf 10 days after infection.

Conclusion: A. leiocarpus or T. macroptera extracts in the inoculum reduced chlorosis and necrosis damages thanks to infiltrated polyphenols but not enough to prevent damages completely.

Keywords: Medicinal plants extracts; Nicotiana tabacum; Pseudomonas aeruginosa PAO1; secondary metabolites.

\section{INTRODUCTION}

Pseudomonas aeruginosa is a Gram-negative bacterium able to infect animals and plants [1]. It is an opportunistic pathogen responsible for many nosocomial infections in humans, particularly in immune compromised or cystic fibrosis patients, leading to high rates of morbidity and mortality [2].The bacteria has a coordination system for the expression of virulence factors called Quorum Sensing (QS) depending on the bacterial density. Three systems of QS have been described in $P$. aeruginosa: the Las system, the Rhl system and the Pseudomonas Quinolone Signal (PQS) system. These systems control 8 to $10 \%$ of the $P$. aeruginosa genome [3]. As QS inhibitors may constitute a new class of antibacterial agents, the attenuation of bacterial virulence rather than the destruction of the pathogenic microorganism is a new concept for the control of pathogenic bacteria that are resistant to antibiotics. Anti-QS activity has been demonstrated in several plants belonging to the families of Combretaceae,
Euphorbiaceae and Myrtaceae. [4]. In some plants, isolated flavonoids including catechin and naringenin showed to inhibit the production of $P$. aeruginosa virulence factors [5]. Moreover, ethnobotanical data indicate that the medicinal plants Anogeissus leiocarpus and Terminalia macroptera are rich in flavonoids and have significant anti-bacterial properties against Staphylococcus aureus, Shigella disenteriae and Vibrio cholera $[6,7]$. Our study is in line with the WHO( Word Heath Organization) recommendations [8] on the intensification of the search for medicinal plant treatments associated with $P$. aeruginosa.

The general objective of our work was to study the effect of Anogeissus leiocarpus and Terminalia macroptera extracts on the pathogenicity of the bacterial strain Pseudomonas aeruginosa PAO1 in the tobacco plant (Nicotiana tabacum). So we had to determine the effect of these medicinal plant extracts on $P$. aeruginosa PAO1 induced leaf chlorosis and necrosis, and evaluate the effect of 
extracts on the production of chlorophyll, proteins and phenolic compounds following bacterial infection of leaves.

\section{MATERIALS AND METHODS}

\subsection{Biological Material}

Wild tobacco seeds and bacterial strain of PAO1 were provided by the Laboratory of Plant Biotechnology of the Free University of Bruxelles (FUB) in Belgium. The methanolic extracts of $A$. leiocarpus and T. macroptera were obtained in the Applied Biochemical and Chemistry Laboratory (LABIOCA) of the University Joseph $\mathrm{KI}$-ZERBO in Burkina Faso.

\subsection{In vitro Culture of Tobacco Seeds}

In order to have aseptic plants of Nicotiana tabacum, seeds were sterilized with a solution of $0.75 \%$ sodium hypochlorite and $80 \%$ ethanol. Then in a sterile environment, the solution was removed 5 minutes later and $1 \mathrm{ml}$ of $100 \%$ ethanol was added and then removed immediately. Finally, the seeds were washed three times with distilled water and then dried for 2 hours. 1/2 MS medium was prepared with phytagel in $450 \mathrm{ml}$ of distilled water. The medium was then sterilized by autoclaving at $120^{\circ} \mathrm{C}$ for 20 minutes. The tobacco seeds were sown in Petri dishes on the culture medium and then placed at $4^{\circ} \mathrm{C}$ for $24 \mathrm{~h}$ in the dark. Then they were placed in a culture chamber at $20^{\circ} \mathrm{C}$ and 16 hours of light. The seedlings 2 weeks old were transferred to pots containing a sterile mixture of 2/4 of breeding ground, 1/4 of manure and 1/4 of fine sand. They were watered with $100 \mathrm{ml}$ of water each day. Two weeks after their transfer to the potting soil, the plants were used for the different treatments.

\subsection{Inoculum Preparation}

Bacterial inoculum was prepared in LB medium to obtain $10^{6} \mathrm{CFU} / \mathrm{ml}$ (colony forming unit) [9].

\subsection{Infiltration of Inoculum in Tobacco Leaves}

Three infiltration conditions were performed according to the inoculum nature: an infection with the PAO1 inoculum and the second one with PAO1 added to $100 \mu \mathrm{g} / \mathrm{mL}$ of plant extract, $A$. leiocarpus or T. macroptera. Infiltration consisted of injecting $100 \mu \mathrm{L}$ of inoculum on the lower leaf surface according to the method of Starkey and
Rahme [9]. For the control condition, no infiltration was done on leaf. After the treatments, tobacco plants were protected in a plastic bag and placed in the grow room.

\subsection{Measurement of Phenotypic Parameters after Leaves Treatments}

Treated plants were observed until the appearance of necrosis on the upper surface of the leaves. The plants were subsequently photographed and their phenotype appreciated. The ImageJ software was used to measure discolored and necrotic areas of treated leaves.

\subsection{Measurement of Biochemical Parameters in Treated Leaves}

\subsubsection{Chlorophylls a and b content}

From $100 \mathrm{mg}$ of fresh leaf, chlorophylls $a$ and $b$ were extracted according to the procedure described by [10]. The absorbance at 663 and $665 \mathrm{~nm}$ led to determine the chlorophylls content in $\mathrm{mg} / \mathrm{g}$ fresh weight $(\mathrm{FW})$ following formulas: chl $a=12^{*}\left(O_{663}\right)-2.67^{*}\left(O_{645}\right)$ and $\mathrm{chl} b=22.5^{*}$ $\left(\mathrm{OD}_{645}\right)-4.68^{*}\left(\mathrm{OD}_{663}\right)$. Three absorbance measurements were made for each sample and the average was calculated.

\subsubsection{Total protein amount}

Protein concentration $(\mathrm{mg} / \mathrm{gFW})$ was determinate according to [11] from $250 \mathrm{mg}$ of fresh leaves crushed in $0.1 \mathrm{M}$ potassium phosphate buffer $\mathrm{pH} 7$ containing $0.1 \mathrm{mM}$ EDTA, $0.1 \mathrm{mM}$ ascorbate. One $\mu \mathrm{l}$ of Bio-Rad reagent was used, different concentrations of BSA serve for standard curve establishment, $10 \mu \mathrm{l}$ of protein extract was used and ODs were read at $595 \mathrm{~nm}$.

\subsubsection{Polyphenols and total flavonoids contents}

The tobacco leaves were crushed and soaked in $1 \mathrm{ml}$ of methanol for 24 hours.

The determination of the total polyphenol was carried out according to the procedure described by [12]. Plant extract was mixed with FolinCiocalteu Reagent and, 5 min later, with sodium bicarbonate. After incubation $(1 \mathrm{H}$, room temperature). The absorbance was read at 760 $\mathrm{nm}$ for a standard curve with different concentrations of gallic acid. Three readings were carried out per sample of extract and the mean expressed in mg Equivalent Gallic Acid per 
$100 \mathrm{mg}$ of dried extract in mg EGA/100 mg Dry Weight (DW).

Total flavonoids were determined by the Dowd colorimetric method adapted by [13]. A $100 \mu \mathrm{l}$ of solution $\mathrm{AlCl}_{3}$ in $2 \%$ was added to $100 \mu \mathrm{l}$ of methanolic extract and to variable concentrations of quercetin, the reference substance for standard curve. Three readings of OD at $415 \mathrm{~nm}$ were performed per extract sample and the results expressed in mg Equivalent Quercetin per $100 \mathrm{mg}$ of dried extract (mg EQ/100 mgDW).

\subsection{Statistical Analyzes of the Data}

Data analysis was performed using the Graph Pad Prism 5 software. One-way ANOVA by Tukey's test was used to compare the averages and the $5 \%$ threshold was retained to show significant differences.

\section{RESULTS AND DISCUSSION}

\subsection{Chlorosis and Necrosis in Treated Leave}

After 10 days of treatment, phenotypic observation shows the damages caused by $P$. aeruginosa infiltration in leaves (Fig. 1). Discolored and necrotic surfaces areas near the infiltration pot, are given in Fig. 2.

The simultaneous infiltration of PAO1 and plant extracts considerably reduced the discolored and necrotic areas of leave comparatively to the
PAO1 inoculation alone (Figs. $2 \mathrm{~A}$ and 2B). Indeed, the discolored area showed a reduction of $50 \%$ when plant extracts have been supplemented in the inoculum. The reduction in necrotic surface was more pronounced when infiltration was done with $\mathrm{P}$. aeruginosa and $\mathrm{T}$. macroptera extract $(88 \%)$ than with $P$. aeruginosa and A. leiocarpus (85\%) both compared to PAO1 alone.
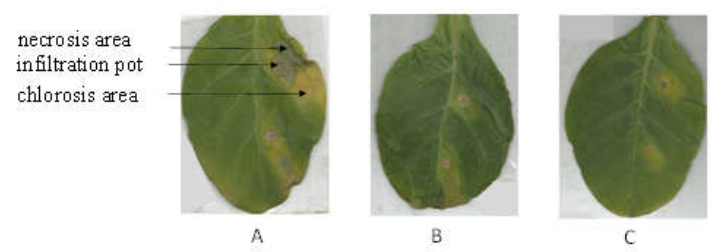

Fig. 1. Leaves of $N$. tabacum after 10 days of treatments

$A$ : Leaf treated with $P$. aeruginosa; $B$ : Leaf treated with $P$. aeruginosa $+A$. leiocarpus; $C$ : Leaf treated with $P$. aeruginosa+T. macroptera

The apparent yellow spots on the treated leaves (Fig. 1) are symptoms of a decrease in chlorophyll content [14]. The similar pronounced necrosis on the leaf of $\mathrm{N}$. tabacum infected with $P$. aeruginosa alone after 10 days (Fig. 1A) has been also seen on some plants such as Ocimum basilicum when infected with $P$. aeruginosa PAO1 or PA14 [15]. It can be explained by the presence of toxic compounds produced by $P$. aeruginosa which the most toxic is exotoxin $A$ (ETA) with a LD50 of $0.2 \mathrm{mg}[16,17,18]$. ETA

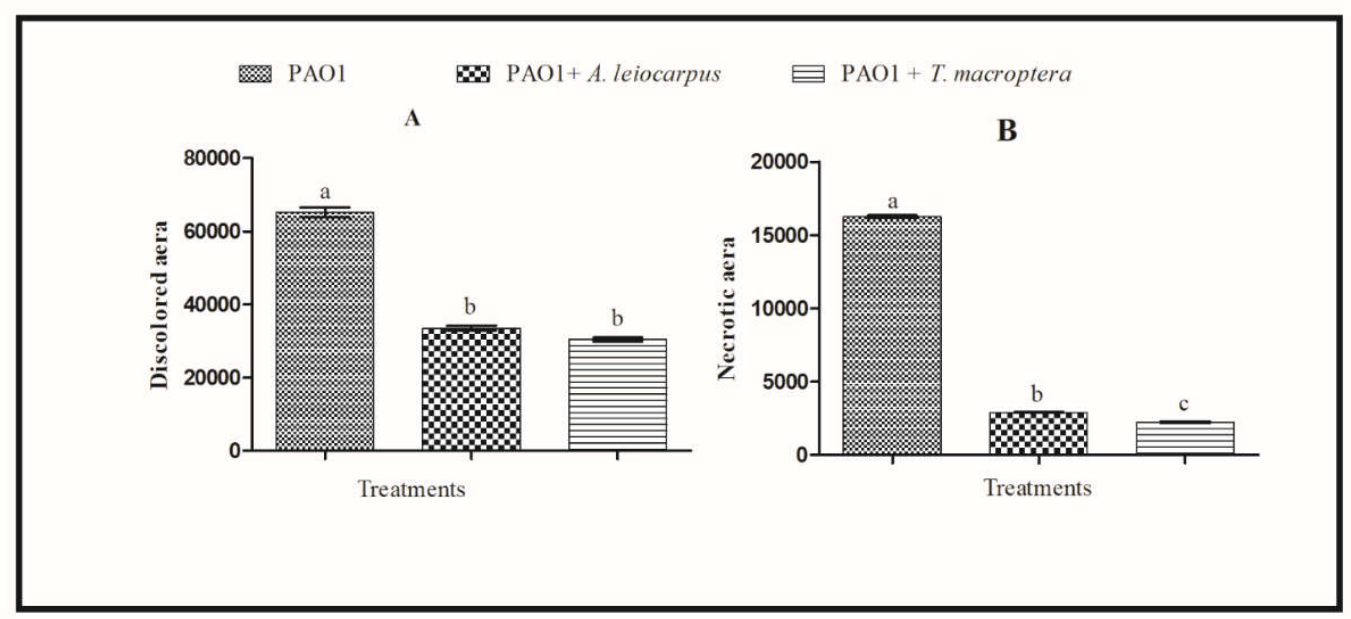

Fig. 2. Discolored and necrotic surfaces of treated leaves

$A$ : Discolored area in treated leaf; $B$ : Necrotic area in treated leaf

PAO1: treatment with $P$. aeruginosa; $P A O 1+A$. leiocarpus: treatment with $P$. aeruginosa+A. leiocarpus; PAO1

$+T$. macroptera: treatment with $P$. aeruginosa+T. macroptera

Values with different letters are significantly different at $P<.05$ 
specifically interacts with a receptor on the surface of the host cell and affects protein synthesis thus causing the death of the target cell. Rhamnolipids produced by the bacterium could also lead to cell death considering their detergent property[19]. The observed necrosis can also result from an accumulation of toxic molecules produced by the plant for fighting the pathogen, but then harmful to the plant itself. Considering the resistance of $P$. aeruginosa to many antibiotics [20] it is possible to think about an accumulation of these "antibacterial" molecules in leaves due to their lack of effectiveness against the bacteria. Among these defense molecules, appear reactive oxygen species with free radicals such as hydroxyl radical $\left({ }^{\bullet} \mathrm{OH}\right)$, superoxide radical $\left(\mathrm{O}^{\bullet-}\right)$ but also non-radical forms including $\mathrm{H}_{2} \mathrm{O}_{2}$ hydrogen peroxide can cause bleaching and cell death [14]. However, the involvement of these oxidized species should be considered in the process of programmed cell death causing necrotic lesions around the point of infection to isolate the pathogens [21].The phenotypic parameters thus studied, foliar necrosis and chlorosis, allowed us to conclude that $P$. aeruginosa has a pathogenic potential on the studied variety of tobacco. Considering our results and some studies which showed an antibacterial activity of zincassociated nicotine of tobacco against different Gram-positive and Gram-negative bacterial strains [22], it appears that either the variety of tobacco used is sensitive to $P$. aeruginosa or that the PAO1 strain is highly pathogenic.

According to Fig. 2A leaves infected with $P$. aeruginosa PAO1 alone showed a discolored surface twice as large as those treated with $T$. macroptera extract or A. leiocarpus. Considering the same discolored areas for both extracts treatment, it appears that the action of the two extracts is similar and consists in reducing the spread of chlorosis caused by the bacterium. Furthermore, the application of these two medicinal plant extracts which significantly reduced the necrotic surface area compared to the infiltration with $P$. aeruginosa alone (Fig. 2B) showed that plant extracts reduced the bacterialinduced necrosis process in this tobacco variety. Thus, we can admit that the $P$. aeruginosa PAO1 bacterial strain is involved in the onset of symptoms of necrosis and that the action of medicinal plant extracts would reduce its virulence. The content of these extracts in secondary metabolites such as gallic acid and myricetin could be the source $[23,24]$. Our results also showd a more reduction of necrotic surface in leaves treated with $T$. macroptera extract compared to those treated with $A$. leiocarpus extract (Fig. 2B). T. macroptera seems to be the most effective extract plant on foliar necrosis.

\subsection{Chlorophyll and Protein Content in Treated Leaves}

In the presence of plant extracts, chlorophyll a quantity was less reduced whereas no difference in chlorophyll $b$ content was observed between PAO1 and PAO1+extracts ( $A$. leiocarpus or $T$. macroptera) treatment on leaves. Only $A$. leiocarpus extract led to rise up the protein content (Fig. 3) when compared to PAO1 infiltration condition.

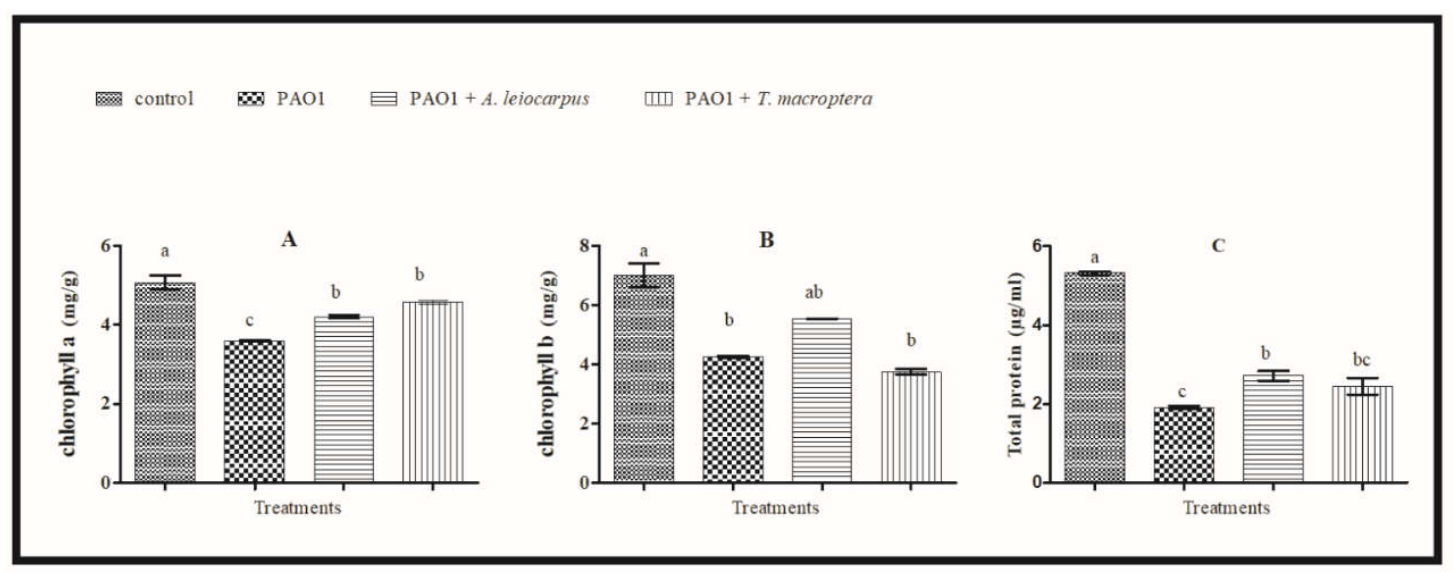

Fig. 3. Leaf chlorophyll and protein contents after 10 days of treatment

A: Chlorophyll a content; $B$ : Chlorophyll b content; $C$ : Protein content

PAO1: treatment with $P$. aeruginosa; PAO1+A. leiocarpus: treatment with $P$. aeruginosa+A. leiocarpus; PAO1+T. macroptera: treatment with $P$. aeruginosa+ $T$. macroptera

Values with different letters are significantly different at $P<.05$ 
The decrease in chlorophyll amount in the discolored leaves confirm the apparent chlorosis following the PAO1 infection comparing to the control (Figs. 3A and 3B). The drop in chlorophyll $a$ and $b$ content probably result from their degradation/oxidation or from an inhibition of their synthesis [14]. Their oxidation by the reactive oxygen species produced during biotic stress induces leaf bleaching resulting in chlorosis [25]. The chlorophylls synthesis could be affected by oxidation of enzymes involved in the synthesis pathway in the case of programmed chlorosis or even by a degradation/inhibition of these enzymes by $P$. aeruginosa virulence factors $[3,26]$. The application of the two plant extracts, $A$. leiocarpus and $T$. macroptera, similarly improved the amount of chlorophyll a but did not change the chlorophyll content $b$. The antibacterial effect of the extracts observed on chlorophyll is thus not verified on chlorophyll $b$, thus suggesting a specificity of the antibacterial action relating to the type of chlorophyll pigment. Plant extracts would attenuate the virulence of the bacterium by inhibiting certain pathogenic enzymes affecting the chlorophyll a synthesis pathway and/or by trapping excess free radicals $[27,28]$.

Total protein content decreased 10 days after PAO1 treatment compared to the control (Fig. $3 C$ ) and stipulates a degradation of proteins, a disruption of the translation or even of the transcription of some genes following the infection. Proteins degradation may be due to their oxidation by reactive oxygen species or to the proteolytic activity of certain virulence factors such as elastase [14,29,30,1]. Such oxidative and proteolytic activities on proteins as elongation and transcription factors can lead to an inhibition of translation and/or transcription of target genes. Furthermore, some oxidative molecules may interact with membrane proteins and lipids leading to disintegration of cell membranes $[14,19]$. In the presence of medicinal plant extract, only the case where $P$.aeruginosa was associated with $A$. leiocarpus extract showed a significant increase in total leaf protein content compared to PAO1 treatment (Fig. $3 \mathrm{C}$ ). This result suggests that the compounds in $A$. leiocarpus extract slow the proteolysis or tend to suppress the inhibitory effect of PAO1 proteins by "protecting" the leaf proteins with chemical binding or by binding to the active site of bacterial enzymes. The role of tannins as a trap for reactive oxygen species is significant in the protection of foliar proteins [31]. So, A. leiocarpus extract appears to have a better efficiency on the proteolysis and/or the inhibition of bacterial enzymes.

\subsection{Content in Secondary Metabolites}

Only $T$. macroptera extract lowered the overall level of total polyphenol in leaf (Fig. 4A). It also strongly reduced the total endogenous flavonoid content comparing to others treatments (Fig. 4B).

Infection of the leaf with $P$. aeruginosa PAO1 has increased the total polyphenol production compared to the control (Fig. 4A). Infected plant seems to induce defense mechanism that

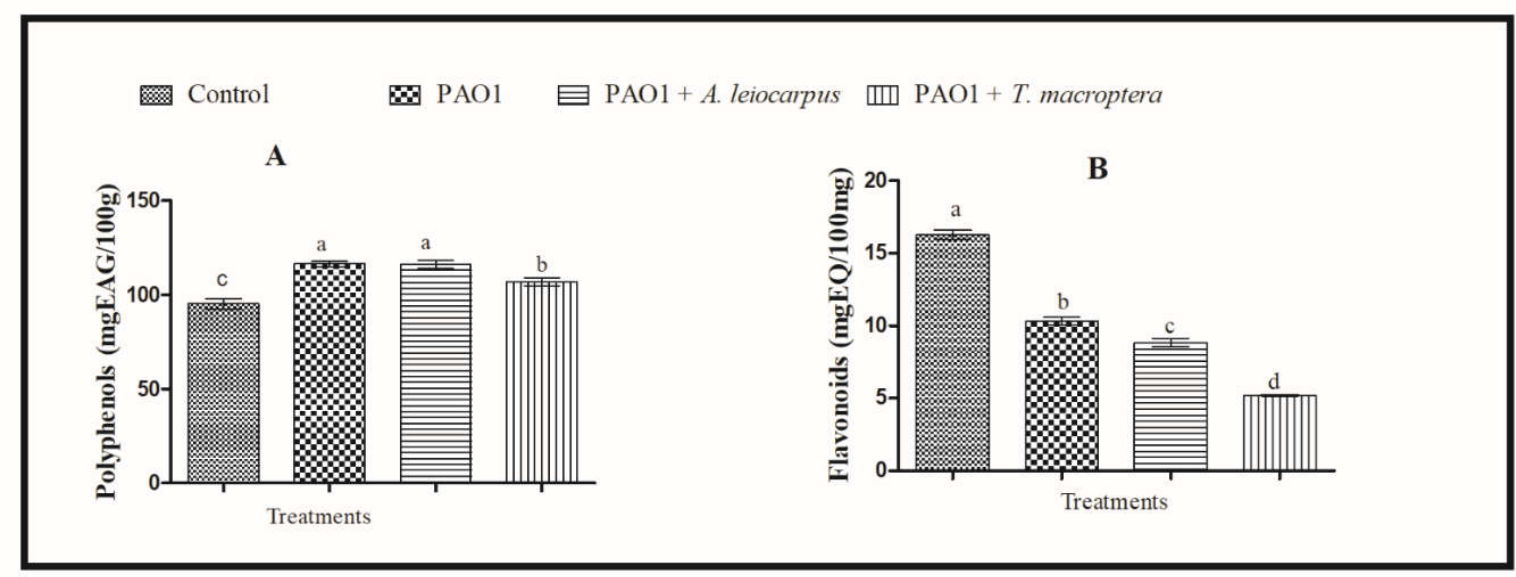

Fig. 4. Total polyphenol and flavonoid content in leaves after 10 days of treatment A: Total polyphenol content; $B$ : Total flavonoid content

PAO1: treatment with P. aeruginosa; PAO1+A. leiocarpus: treatment with P.aeruginosa+A.leiocarpus; $P A O 1+T$. macroptera: treatment with $P$. aeruginosa $+T$. macroptera

Values with different letters are significantly different at $P<.05$ 
produce polyphenols against infection. Only the addition of the extract of $\mathrm{T}$. macroptera to the PAO1 inoculum lowered the total foliar polyphenols but did not reach the level observed in the control plants. This result suggests that $T$. macroptera extract contains polyphenols helping plant to fight bacterial attack but insufficient to prevent the production of plant own polyphenols. A. leiocarpus extract seems to have very few polyphenol hence the high level of plant polyphenol. It is conceivable that 10 days after the infiltration the quantity of polyphenols in plant extract became insufficient for bacterial attack thus forcing plant to produce polyphenols. Regarding flavonoids content, Fig. 4B shows us that flavonoids appear to be little involved in the defense response of the tobacco plant to pathogenic attack. It is possible to believe in their early effective action during the first moments after infiltration, or in their degradation as a result of infection, or more likely in a decrease of their production to the benefit of other(s) type(s) of polyphenols which are involved in tardive but effective defense response.

\section{CONCLUSION}

From our results, it is clear that the studied medicinal plant extracts significantly reduce the extent of necrotic lesions caused by $P$. aeruginosa PAO1. The total polyphenol content of PAO1 $+T$. macroptera treated leaves shows the involvement of exogenous polyphenols and that $T$. macroptera extract is the best extract for necrotic process inhibition. The discolored foliar surface due to the chlorosis followed an inverted trend with the content of chlorophyll a, thus mentioning a less pronounced degradation (or even a better protection) of the chlorophyll a assured by the presence of the extracts. The amount of total leaf protein less affected when $A$. leiocarpus extract was added to the inoculum stipulates that this extract boosts leaf protein production. Into perspectives, it is interesting to use more concentrated extract to find the best concentration for a total inhibition of chlorosis and necrosis. Also, some dosages of polyphenols, chlorophyll and proteins at different early times after infiltration can elucidate the role of these medicinal plant extracts on bacterial resistance. It might also be possible to identify the individual phenolic acids and flavonoids involved in the defense response.

\section{ACKNOWLEDGEMENTS}

The authors are grateful to the world academy of science (twas) for the financial support provided under the research grant 12-044/rg/bio/af/ac-g-unescofr: 3240271326.

\section{COMPETING INTERESTS}

Authors have declared that no competing interests exist.

\section{REFERENCES}

1. Rahme LG, Ausubel FM, Cao H, Drenkard E, Goumnerov BC, Lau GW, et al. Plants and animals share functionally common bacterial virulence factors. Proc. Natl. Acad. Sci. USA 2000; 97(16):8815-8821.

DOI: 10.1073/pnas.97.16.8815

2. Bricha S, Ounine K, Oulkheir S, EL Haloui $\mathrm{NE}$, Attarassi B. Facteurs de virulence et epidemiologie liés à Pseudomonas aeruginosa. Rev. Tunis. d'Infect.2009; 2:714 . .

3. Le Berre R, Faure K, Nguyen S, Pierre M, Ader F, Guery G. Quorum Sensing: a new clinical target for Pseudomonas aeruginosa. J. Medmal. 2006;(10):1016.

DOI: 10.1016/j.medmal.2006.01.008

4. Adonizio A Kong K, Mathee K. Inhibition of quorum sensing-controlled virulence factor production in Pseudomonas aeruginosa by South Florida plant extracts. Antimicrob. Agents Chemother. 2008; 52(1): 198-203. DOI: 10.1128/AAC.00612-07

5. Vandeputte OM, Kiendrebeogo $M$, Rajaonson S, Diallo B, Mol A, El Jaziri M et al. Identification of catechin as one of the flavonoids from Combretum albiflorum bark extract that reduces the production of quorum-sensing-controlled virulence factors in Pseudomonas aeruginosa PAO1. Appl. Environ. Microbiol. 2010; 76(1): 243-253.

DOI: 10.1128/AEM.01059-09

6. Silva O, Serrano R.Terminalia genus as source of antimicrobial agent. battle agains Microb. Pathog. basic Sci. Technol. Adv. Educ. programs. 2015; 236-245.

7. Traoré $Y, K$. Ouattara K, Ouattara A, Méité $\mathrm{S}$, Bagré I,Konan KF et al. Evaluation of the Antistaphylococcic Activity of Terminalia macroptera Guill et Perr (Combretaceae) Stem Bark Extracts. Am. J. Biosci. 2015;3(6):221-225.

DOI: 10.11648/j.ajbio.20150306.14

8. OMS, coup d'oeil sur la santé. Profil pays, Bangui. Centrafrique RCA; 1995.

9. Starkey M, Rahme LG. Modeling Pseudomonas aeruginosa pathogenesis in 
plant hosts. Nat. Protoc. 2009;4(2):117124.

DOI: 10.1038/nprot.2008.224

10. Ferus M, Arkosiova P. Variability of chlorophyll content under fluctuating environment. Acta Fytotech. Zootech. (In Proc. Int. Sci. Conf. Occas. 55th Anniv. Slovak Agric. Univ. Nitra 123). 2001;4.

11. Lamien-Meda A, Lamien CE, Compaoré MMY, Meda RNT, Kiendrebeogo M, Zeba $B$, et al. Polyphenol content and antioxidant activity of fourteen wild edible fruits from Burkina Faso. Molecules. 2008;13:581-594.

12. Singleton VL, Orthofer R, LamuelaRaventos RM. Analysis of total phenols and other oxidation substrates and antioxidants by means of Folin-Ciocalteu Reagent," Methods Enzymol. 1999; 299 :152-178.

DOI: 10.1016/S0076-6879(99)99017-1

13. Arvouet-Grand A, Vennat B, Pourrat A, Legret $P$. Standardisation d'un extrait de propolis et identification des principaux constituants. J. Pharm. Belgique.1994;49(6):462-68.

14. Parent C, Capelli N, Dat J.Formes réactives de l'oxygène, stess et mort cellulaire chez les plantes. C. R. Biol. 2008;331:255-261.

DOI : 10.1016/j.crvi.2008.02.001

15. Walker TS, Bais HP, Déziel E, Schweizer HP, Rahme LG, Fall R et al. Pseudomonas aeruginosa -Plant Root Interactions. Pathogenicity, Biofilm Formation, and Root Exudation. Plant Physiol. 2004;134:320-331.

16. Iglewski B, Sadoff JT. Toxin inhibitors of protein synthesis: production Purification, and assay of Pseudomonas aeruginosa toxin A. Methods Enzym. 1979;60:93-780. DOI: 10.1016/s0076-6879(79)60071-x

17. D'Argenio DA, Gallagher LA, Berg CA, Manoil C. Drosophila as a Model Host for Pseudomonas aeruginosa Infection. J. Bacteriol. 2001;183(4):1466-1471.

DOI: 10.1128/JB.183.4.1466-1471.2001

18. Gallant C, Raivio T, Olson J, Woods D, Storey D. Pseudomonas aeruginosa cystic fibrosis clinical isolates produce exotoxin $A$ with altered ADP ribosyltransferase activity and cytotoxicity. Microbiol. 2000;146:1891-1899.

DOI: 10.1099/00221287-146-8-1891

19. Jensen $P O$, Bjarnsholt $T$, Phipps $R$, Rasmussen TB, Calum H, Christoffersen L et al, Rapid necrotic killing of polymorphonuclear leukocytes is caused by quorum sensing- controlled production of rhamnolipid by Pseudomonas aeruginosa. Microbiology. 2007;153:13291338.

DOI: $10.1099 / \mathrm{mic} .0 .2006 / 003863-0$

20. [20] Hirsch E, Tam V. Impact of multidrug-resistant Pseudomonas aeruginosa infection on patient outcomes. Expert Rev Pharmacoecon Outcomes Res. 2010;10(4):441-51.

DOI: $10.1586 /$ erp. 10.49

21. Torres MA, Jones JDG, Dangl JL. Reactives oxygène species signaling in response to pathogens. Plant physiol. 2006;141(2):373-378.

DOI: $10.1104 / p p .106 .079467$

22. Zaidi MI, Wattoo FH, Wattoo MHS, Tirmizi SA. Antibacertrial activities of nicotine and its Zinc complex. African J. Microbiol. Res. 2012;6(24):5134-5137.

23. Ouédraogo $\mathrm{V}$, Kiendrebeogo M. Methanol Extract from Anogeissus leiocarpus (DC) Guill. et Perr. (Combretaceae) Stem Bark Quenches the Quorum Sensing of Pseudomonas aeruginosa PAO1. Medicines. 2016;3(4):26.

DOI: $10.3390 /$ medicines 3040026

24. Premkumar J, Meena KS, Chu Sing L., Thean Hock T, Kishore R S. Activity and interactions of Antibiotic, and phytochemical combinations Against Pseudomonas aeruginosa in vitro. Int $\mathrm{J}$ Biol Sci. 2010;6(6): 556-568.

DOI: $10.7150 / \mathrm{ijbs} .6 .556$

25. Dat JF, Van Breusegem S, Vandenabeele F, Vranova E, Van Montagu M, Inze D. Dual action of active oxygen species during plant stress responses. Cell. Mol. Life Sci. 2000;57:779-795.

26. Le Berre R, N. S, N. E, K. E, P.M et al. Ader F, Quorum sensing activity and related virulence factor expression in clinically pathogenic isolates of Pseudomonas aeruginosa. Clin Microbiol Infect. 2008;14(4):337-43.

DOI: 10.1111/j.1469-0691.2007.01925.x

27. Jabs $T$. Reactive oxygen intermediates as mediators of programed cell death in plants and animals. Biochem. Pharmacol. 1999;57:231-245.

DOI: 10.1016/s0006-2952(98)00227-5.

28. Krief S. Métabolites secondaires des plantes et comportement animal: surveillance sanitaire et observations de l'alimentation de chimpanzés (Pantroglodytes schweinfurthii) en 
Ouganda; activités biologiques et étude chimique de plantes consommées; 2003.

29. Lyczak JB, Cannon CL, Pier GB. Establishment of Pseudomonas aeruginosa infection: lessons from a versatile opportunist. Microbes Infect. 2000;2(9):1051-1060.

DOI: $10.1016 / \mathrm{s} 1286-4579(00) 01259-4$.

30. Cao H, Glazebrook J, Clarke JD, Volko S Dong X. The Arabidopsis NPR1 Gene That
Controls Systemic Acquired Resistance Encodes a Novel Protein Containing Ankyrin Repeats. Cell.1997; 88: 57-63. DOI: 10.1016/S0092-8674(00)81858-9

31. War AR, Paulraj MG, Ahmad T, Ahad A, Hussain $B$, Ignacimuthu $S$, et al. Mechanisms of plant defense against insect herbivores Mechanisms of Plant Defense against Insect Herbivores. 2012;2324.

(c) 2020 Ouédraogo et al.; This is an Open Access article distributed under the terms of the Creative Commons Attribution License (http://creativecommons.org/licenses/by/4.0), which permits unrestricted use, distribution, and reproduction in any medium, provided the original work is properly cited. http://www.sdiarticle4.com/review-history/61801 